\title{
Identification of Specific Sites of Hormonal Regulation in Spermatogenesis in Rats, Monkeys, and Man
}

\author{
R.I. McLachlan,* L. O’Donnell,* S.J. Meachem,* P.G. Stanton,* \\ D.M. de Kretser, ${ }^{\dagger}$ K. Pratis, ${ }^{*}$ and D.M. Robertson* \\ *Prince Henry's Institute of Medical Research, Monash Medical Centre, Clayton, Victoria, 3168, \\ Australia; ${ }^{\dagger}$ Monash Institute of Reproduction and Development, Monash University, \\ Monash Medical Centre, Clayton, Victoria, 3168, Australia
}

\begin{abstract}
A detailed understanding of the hormonal regulation of spermatogenesis is required for the informed assessment and management of male fertility and, conversely, for the development of safe and reversible male hormonal contraception. An approach to the study of these issues is outlined based on the use of well-defined in vivo models of gonadotropin/androgen deprivation and replacement, the quantitative assessment of germ cell number using stereological techniques, and the directed study of specific steps in spermatogenesis shown to be hormone dependent. Drawing together data from rat, monkey, and human models, we identify differences between species and formulate an overview of the hormonal regulation of spermatogenesis. There is good evidence for both separate and synergistic roles for both testosterone and follicle-stimulating hormone (FSH) in achieving quantitatively normal spermatogenesis. Based on relatively selective withdrawal and replacement studies, FSH has key roles in the progression of type A to B spermatogonia and, in synergy with testosterone, in regulating germ cell viability. Testosterone is an absolute requirement for spermatogenesis. In rats, it has been shown to promote the adhesion of round spermatids to Sertoli cells, without which they are sloughed from the epithelium and spermatid elongation fails. The release of mature elongated spermatids from the testis (spermiation) is also under FSH/testosterone control in rats. Data from monkeys and men treated with steroidal contraceptives indicate that impairment of spermiation is a key to achieving azoospermia. The contribution of $5 \alpha$-reduced androgens in the testis to the regulation of spermatogenesis is also relevant, as $5 \alpha$-reduced androgens are maintained during gonadotropin suppression and may act to maintain low levels of germ cell development. These concepts are also discussed in the context of male hormonal contraceptive development.
\end{abstract}

\section{Introduction}

Despite impressive technical advances in human reproductive medicine (e.g., assisted reproductive technologies, new drugs, and recombinant hormones), there remain many important questions about male fertility regulation. In the area of spermatogenesis, such deficiencies exist in the areas of hormonal male contraception, complete spermatogenic failure, damage from toxic/environmen- 
tal agents, and in understanding hypothalamo-pituitary-testicular relationships in infertile or aging men.

We have focused on the hormonal regulation of spermatogenesis with a view to testing, whenever possible, observations made in lower mammals (primarily rodents) for their relevance to man. In this review, we will provide an overview of the hormonal regulation of spermatogenesis in all these species, drawing together common features and highlighting important differences, particularly in regard to monkeys and man.

\section{A. OVERVIEW OF THE HYPOTHALAMIC-PITUITARY-TESTIS AXIS}

The production of spermatozoa (fertility) and the secretion of testosterone (virility) by the testis are both dependent on stimulation by the pituitary gonadotropins, follicle-stimulating hormone (FSH) and luteinising hormone (LH), which are secreted in response to hypothalamic gonadotropin-releasing hormone $(\mathrm{GnRH})$. Testosterone $(\mathrm{T})$, which is essential for the initiation and maintenance of spermatogenesis, is secreted by the adult Leydig cell under LH stimulation. Testosterone acts via androgen receptors (ARs) on Sertoli, Leydig, and peritubular cells. The fact that $\mathrm{T}$ exerts its effects on somatic cells rather than germ cells was highlighted by recent germ cell transplantation studies (Johnston et al., 2001) in which spermatogonia from AR-deficient animals developed into spermatozoa in wild-type recipients. FSH acts via specific G protein-coupled surface receptors located exclusively on Sertoli cells. FSH has a key role in the development of the immature testis, particularly by controlling Sertoli cell proliferation (Orth, 1993). Following many conflicting data in animal and human models, there is now general agreement that some degree of complete spermatogenesis can be initiated and maintained in the apparent absence of FSH. However, quantitatively normal spermatogenesis in adulthood is dependent on FSH, certainly in man and monkeys. FSH secretion is regulated by negative feedback from the testicular hormone, inhibin B, and through testosterone, either alone or by its aromatisation to estradiol (Hayes et al., 2001).

\section{B. OVERVIEW OF SPERMATOGENESIS AND APPROACH TO ITS STUDY}

Many in vitro and in vivo model systems have been used to study regulation of spermatogenesis by FSH and T, each with varying strengths and weaknesses. Often, reports using these models extrapolate the principle findings to other species, with limited justification. In addition, conclusions may be affected by whether the model system is one of congenital deficiency of hormone secretion or action, as opposed to one involving spermatogenic restoration or maintenance in adulthood. The degree of gonadotropin deficiency may be difficult to establish due to the limited sensitivity of gonadotropin assays used in many test species. 
Finally, the descriptions of the changes in germ cell populations may be only qualitative, while properly validated quantitative methods (stereological methods) are preferred. Before undertaking a review of the effects and sites of hormone action on spermatogenesis, we will briefly highlight some aspects of the underlying physiology and the approaches to its study.

Spermatogenesis involves four basic processes: spermatogonial development (stem cell and subsequent cell mitotic divisions), meiosis (DNA synthesis and two meiotic divisions to yield haploid spermatids), spermiogenesis (spermatid development involving differentiation of head and tail structures), and spermiation (the process of release of mature sperm into the tubule lumen). These occur along similar lines in all mammals and are well described at the morphological level (Leblond and Clermont, 1952; Clermont, 1972; de Kretser and Kerr, 1988; Russell et al., 1990). In rodents and some primate species (e.g., Macaca fascicularis), germ cell development occurs in orderly and recognizable cell associations (or stages) along the seminiferous tubule, such that a single stage can be seen within a tubule cross section (Russell et al., 1990). However, in humans and some other primates (e.g., marmosets), the stages are arranged in an intertwining helical pattern such that a single tubule cross section may have up to six identified stages represented (Schulze and Rehder, 1984). Such an arrangement makes the systematic stage-based counting of germ cell populations, as well as the stage-specific detection of proteins or mRNA species of interest, difficult, although possible.

\section{THE STEREOLOGICAL APPROACH TO THE STUDY OF SPERMATOGENESIS}

Relative to primates, a greater range of experimental paradigms are available in rodents for the study of the relative contributions of FSH and LH/T. The ease of obtaining testicular tissue in lower mammals for quantitative analyses has made it easier to ascribe specific FSH or T effects to particular stages or germ cell types. To provide quantitative data on germ cell number, we have focused on the use of unbiased stereological approaches, particularly the thick section optical disector model, in combination with a systematic random sampling scheme (for a review, see Wreford, 1995). This procedure involves the visualisation of complete cell profiles in thick $(25 \mu \mathrm{m})$ sections and has the particular advantage of allowing assessment of irregularly shaped cellular forms, such as differentiating spermatids and spermatozoa, which was not possible with earlier geometric-based methods. In our studies, we have expressed the data as germ cell number per testis. In primates and man, where biopsies are normally used, data are expressed on a per Sertoli cell basis, as the number of Sertoli cells does not alter in response to hormonal manipulation in either primates (Zhengwei et al., 1998c) or humans (Zhengwei et al., 1998b). The expression of data on a 
per-tubule cross-sectional basis is not appropriate as a general rule, as a reduction in tubule volume is seen following hormonal withdrawal (Zhengwei et al., 1998c).

Inherent in the interpretation of germ cell data derived by stereological techniques is the knowledge that the duration of spermatogenesis under the various treatments proposed is known and that it remains unchanged. Animal models based on bromodeoxyuridine or tritiated thymidine labeling have been used to determine the duration of the spermatogenic cycle in monkey and humans. The duration of one cycle of the seminiferous epithelium is $\approx 10$ days in monkeys (de Rooij et al., 1986; Aslam et al., 1999) and 16 days in the human (Heller and Clermont, 1963). Rodent, primate, and human data suggest that the duration of spermatogenesis cannot be altered by modulation of the gonadotropin environment (e.g., hypophysectomy) (Clermont and Harvey, 1965) or by GnRHantagonist treatment of rats or cynomolgus monkeys (Aslam et al., 1999). Our studies in testosterone-treated cynomolgus monkeys suggest that stage frequency (which approximates stage duration) is not affected by the resulting gonadotropin suppression (O'Donnell et al., 2001a). Limited studies in man also suggest that the length of the spermatogenic cycle is not affected by hormone treatment (Heller and Clermont, 1964).

\section{Models Used to Explore Rat Spermatogenesis}

\section{A. MODELS OF TESTOSTERONE DEFICIENCY}

The concentration of testosterone in the rat testis is normally 50 -fold higher than that in serum. It exerts a biphasic effect on spermatogenesis by both inhibiting and promoting the process in vivo, depending on the dose administered (Walsh and Swerdloff, 1973; Sun et al., 1989; Zirkin et al., 1989). Administration of a low dose of T, often as 2.5- to 3-cm T-filled Silastic implants, in combination with a low dose of estradiol (E) (0.1- to 0.4-cm implant, TE implants) causes slightly supraphysiological circulating $\mathrm{T}$ levels that suppress LH, but not FSH secretion (Awoniyi et al., 1989b,1990; McLachlan et al., 1994a; O'Donnell et al., 1994). Accordingly this "TE model" is one of isolated LH/T suppression, a response that is peculiar to rats, and a fact that underlies the very different spermatogenic response to similar treatments in primates (see below). Restoration of sperm production occurs in a dose-responsive manner by the administration of higher doses of T (Awoniyi et al., 1989b,1990; McLachlan et al., 1994a; O'Donnell et al., 1994).

The administration of TE implants to adult rats for 6-12 weeks causes the suppression of testicular T levels to approximately 3\% of normal (O'Donnell et al., 1994,1999) and testicular elongated spermatid production ceases (McLachlan et al., 1994a; O'Donnell et al., 1994). Quantitation of testicular germ cell 
populations during TE suppression and high-dose $\mathrm{T}$ restoration has allowed an understanding of the sites of $\mathrm{T}$ action in germ cell development in the presence of FSH (McLachlan et al., 1994a; Meachem et al., 1998). Using the optical disector stereological approach, studies in TE-treated rats show that spermatogonia and early spermatocytes are suppressed to $\approx 80 \%$ of control, with less suppression of pachytene spermatocytes in stages I-VIII $(\approx 60 \%$ of control $)$ and pachytene spermatocytes in later stages ( $\approx 33 \%$ of control) (Figure 1$)$ (Meachem et al., 1997,1998). Early round spermatids in stages I-VII are suppressed to $\approx 20 \%$ of normal, yet round spermatids in stage VIII are more markedly suppressed to $5 \%$ of normal and elongated spermatids are undetectable (Meachem et al., 1998). Spermatogenesis can be restored to near-normal levels with the replacement of higher-dose T implants (McLachlan et al., 1994a).

FSH is also important in maintaining germ cell development in the TE model. During the restoration of spermatogenesis using higher-dose $\mathrm{T}$ implants, the co-administration of an FSH antibody (see section II-B) to suppress the action of FSH results in significant reductions in various germ cells, most notably, spermatocytes and early spermatids (Meachem et al., 1998). As will be discussed below, there is evidence for complementary and synergistic effects of FSH and $\mathrm{T}$ on germ cell development.

These stereological studies have identified a progressive decline in germ cell number throughout spermatogenesis with $\mathrm{T}$ withdrawal. It has become apparent that sperm release (spermiation) is also affected by this treatment; instead of detaching from the epithelium, mature spermatids are retained by the Sertoli cell, then phagocytosed and thus fail to spermiate. The appearance of mature spermatids retained within the seminiferous epithelium after hormone suppression is well known (Russell and Clermont, 1977; Russell, 1991). We recently used TE suppression and stereological techniques to quantify the extent to which sperm fail to be released and showed that $16 \%, 45 \%, 70 \%$, and $97 \%$ of sperm failed to be released after 1, 2, 3, and 4 weeks of TE treatment, respectively (Saito et al., 2000). After 6 weeks of treatment, however, earlier germ cell populations decreased to a point where no elongated spermatids are produced and thus disruptions to spermiation are not as evident in chronic suppression models (Figure 1). Therefore spermiation failure is an early feature of gonadotropin suppression in the rat (Saito et al., 2000), although is a feature of both acute and chronic gonadotropin suppression in primates (Section III).

\section{B. ACTIVE IMMUNISATION AGAINST GNRH OR GNRH ANTAGONIST TREATMENT IN RATS}

The loss of GnRH action following either of these modalities results in severe combined FSH and LH deficiency, with serum FSH levels falling to below the limit of assay detection and intratesticular $\mathrm{T}$ levels to $\approx 1-2 \%$ of control, 


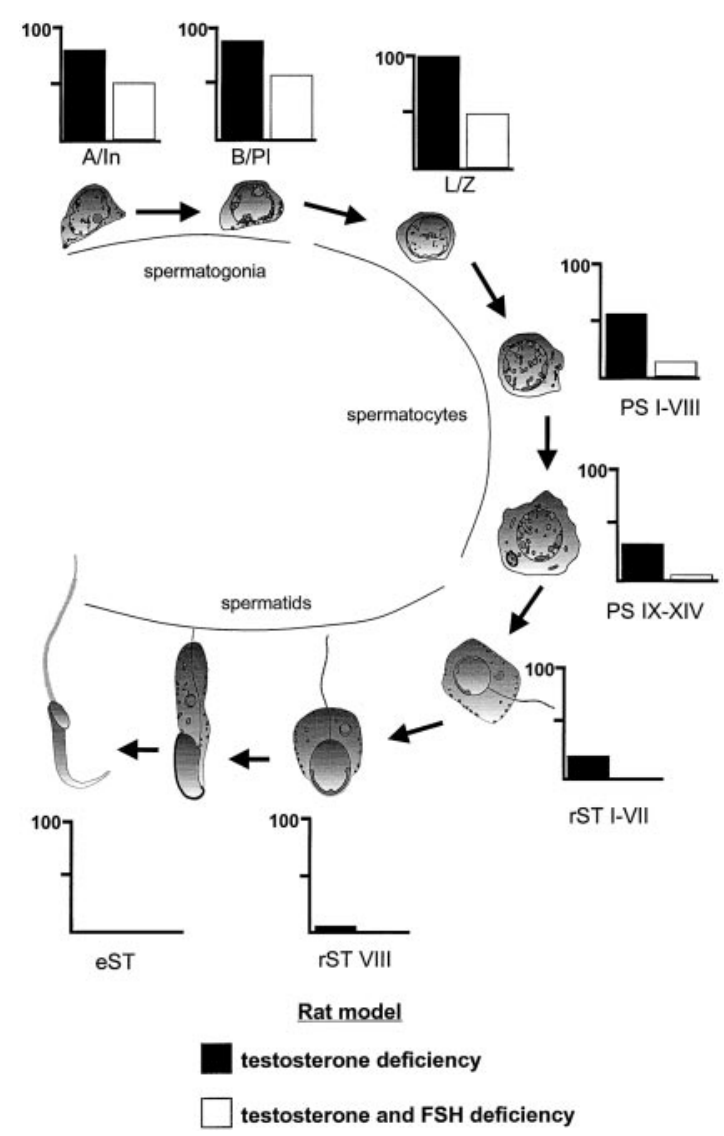

FIG. 1. Comparison of germ cell populations in rats after long-term testosterone (T) suppression or long-term suppression of both T and FSH. Germ cell development from immature spermatogonia through to elongated spermatids is shown, together with stereological data on each germ cell population. Germ cell numbers per testis were determined by the optical disector technique and are expressed as a percentage of an untreated control group. Data were adapted from a previous study (Meachem et al., 1998). The model of $\mathrm{T}$ deficiency utilised adult rats $(\mathrm{n}=6)$ given $3-\mathrm{cm} \mathrm{T}$ and 0.4-cm E implants for 9 weeks to cause the suppression of LH to undetectable levels (O'Donnell et al., 1994) and testicular T to <3\% of controls (O'Donnell et al., 1994; Meachem et al., 1998). Serum FSH levels in this model are either slightly or not significantly altered (O'Donnell et al., 1994,1996a; Meachem et al., 1998). Thus, this is a model primarily of LH/T deficiency. The model of T and FSH deficiency utilised adult rats $(n=6)$ administered a GnRH immunogen for 3 months to suppress LH and FSH to undetectable levels (McLachlan et al., 1994b) and testicular T to $<4 \%$ of controls (Meachem et al., 1998). Abbreviations: A, type A spermatogonia; In, intermediate spermatogonia; B, type B spermatogonia; Pl, preleptotene spermatocytes; L, leptotene spermatocytes; Z, zygotene spermatocytes; PS I-VIII, pachytene spermatocytes in stages I-VIII; PS IX-XIV, pachytene spermatocytes in stages IX-XIV; rST I-VII, round spermatids in stages I-VII; rST VIII, round spermatids in stage VIII; eST, elongated spermatids. 
resulting in severe spermatogenic impairment (Sinha Hikim and Swerdloff, 1993; McLachlan et al., 1994b; Kangasniemi et al., 1995). While this may appear a good model for the study of selective FSH and LH/T replacement, in rats, the restoration of serum $\mathrm{T}$ by exogenous $\mathrm{LH}$ or $\mathrm{T}$ treatment also normalises serum FSH (McLachlan et al., 1994b) by a direct action on pituitary FSH $\beta$ secretion (Wierman and Wang, 1990). Thus, to study the effects of LH/T on spermatogenesis, simultaneous neutralisation of serum FSH must be achieved, such as by passive FSH immunisation (Meachem et al., 1998). We have shown that passive immunisation of adult rats with an FSH antiserum for 7 days by subcutaneous (sc) daily injection at a dose of $2 \mathrm{mg} / \mathrm{kg}$ rat results in immunoabsorption and neutralisation of at least $90 \%$ of circulating FSH, with no changes in serum or testicular $\mathrm{T}$ levels. However, it cannot be ruled out that lower levels of biologically active FSH are still circulating. Since rats rapidly develop neutralising antibodies to the antisera using this approach, only short-term effects of FSH withdrawal can be studied (i.e., $\approx 8$ days).

Spermatogenic failure after GnRH immunisation is characterised by the abolition of round spermatids beyond stage VII, with the numbers of earlier germ cells being severely reduced (Awoniyi et al., 1989a; Sinha Hikim and Swerdloff, 1993; McLachlan et al., 1994b). Three months of GnRH immunisation results in spermatogonial number being reduced to $\approx 50 \%$ of normal (Figure 1). Interestingly, spermatogonial number does not fall further, suggesting that only part of the spermatogonial population is regulated by gonadotropins, although it is possible that residual FSH and testicular T may provide some support. Major losses are also seen during spermatocyte development with early spermatocytes (leptotene-zygotene), pachytene spermatocytes in stages I-VIII, and pachytene spermatocytes in stages IX-XIV, with reductions to $45 \%, 13 \%$, and $4 \%$ of control, respectively (McLachlan et al., 1995; Meachem et al., 1998) (Figure 1). Round spermatids are markedly reduced to $<1 \%$ of control and elongated spermatids are not seen. When compared to the TE model (LH/T deficiency), there is a more-marked loss of spermatogonia and spermatocytes, probably due to the effects of FSH withdrawal on spermatogonial proliferation/survival and germ cell apoptosis in the GnRH-immunised model (Figure 1).

In GnRH-immunised animals, the spermatogenic process can be restored to normal (Awoniyi et al., 1989a) or near normal by T treatment (24-cm Silastic implants) (McLachlan et al., 1994b), as determined by elongated sperm content of the testis. We have prevented the T-induced restoration of serum FSH levels in GnRH-immunised rats by co-treatment with an FSH antiserum, thereby enabling the study of the effects of $\mathrm{T}$ alone on the restoration of spermatogenesis (Meachem et al., 1998). Treatment with FSH antiserum blocked the ability of T to restore spermatogenic cell populations, suggesting that FSH is required for the initial phase of spermatogenic restoration in adult rats following chronic gonadotropin suppression (Meachem et al., 1998). 
We have investigated the restorative effects of FSH on germ cell populations by the administration of recombinant human FSH (rhFSH) after gonadotropin suppression. It is clear from such studies that FSH plays a major role in spermatogonial development, as FSH promptly restores spermatogonial number to normal levels after 7 days, while a partial restoration of spermatocyte and spermatid number was observed (Meachem et al., 1998). When rhFSH was administered for up to 14 days, very few round spermatids underwent elongation and mature, elongated (step 15-19) spermatids were almost never seen (McLachlan et al., 1995), supporting the need for $\mathrm{T}$ in spermatid elongation. Further studies are required to determine the long-term effects of FSH on spermatogenic restoration but would require the availability of recombinant rat FSH to counter the bioneutralisation of administered heterologous FSH.

In summary, chronic $\mathrm{T} \pm \mathrm{FSH}$ suppression results in disordered spermatogonial development and disordered progression through meiosis and spermatid development, with evidence for FSH-specific effects on spermatogonia and of T-specific effects on spermiogenesis in stages VII-VIII.

\section{MODELS EXPLORING THE ACUTE WITHDRAWAL OF HORMONES}

Acute suppression models, such as hypophysectomy and GnRH antagonist treatment, have also been useful in clarifying the effects of FSH and T on germ cell development and have been used to demonstrate the role of these hormones in the maintenance of germ cell viability. Acute gonadotropin suppression results in germ cell death, particularly in stages VII and VIII (Russell and Clermont, 1977; Sinha Hikim and Swerdloff, 1993) via the apoptotic pathway (Sinha Hikim et al., 1995; Sinha Hikim and Swerdloff, 1999). Apoptosis is particularly evident in preleptotene and pachytene spermatocytes in stages VII-VIII, which would account for the marked losses during spermatocyte development after chronic suppression of either $\mathrm{T}$ alone or of FSH and T in rats (Figure 1).

It seems clear from various studies that apoptosis/viability of germ cells can be regulated by FSH and/or T. Germ cell death/apoptosis can be prevented by either T or FSH, with both hormones having a synergistic effect, suggesting that germ cell death in the seminiferous epithelium is regulated by $\mathrm{T}$ and FSH via similar pathways (Russell et al., 1987; Tapanainen et al., 1993; El Shennawy et al., 1998). While acute FSH and T suppression certainly causes an increase in the appearance of degenerating/apoptotic germ cells (Russell and Clermont, 1977), this may or may not lead to significant changes to the viable cell population. For example, 1 week of gonadotropin suppression induced by a GnRH antagonist treatment caused significant decreases in germ cell numbers in stage VII (Sinha Hikim and Swerdloff, 1993), yet 1 week of gonadotropin suppression induced by TE treatment in combination with an FSH antibody did not produce a significant fall in germ cells in this stage (Saito et al., 2000). 
Acute models of gonadotropin suppression have revealed that synergistic effects of FSH and T are evident when one considers spermiation. We have shown that suppression of either FSH or T for 1 week caused $10-15 \%$ of spermatids to be retained. Yet, when both hormones were withdrawn, a moremarked failure (50\%) of spermiation was seen (Saito et al., 2000), suggesting that spermiation is regulated by FSH and T, with both hormones having a synergistic effect. Such studies support earlier observations on the ability of LH and FSH to prevent the retention of mature spermatids (Russell and Clermont, 1977).

An important model to investigate the acute suppression of spermatogenesis is the acute and selective disruption of FSH action in rats in vivo by immunoneutralisation of the FSH protein, which has enabled us to pinpoint sites in the spermatogenic process that are sensitive to FSH withdrawal (Meachem et al., 1999). We observed a time-dependent decline in early germ cell populations in normal rats after FSH antibody ( $\mathrm{Ab}$ ) treatment, demonstrating that FSH plays a major role in spermatogonial development, particularly in the maturation of type A3/A4 spermatogonial subtypes. Loss of spermatocytes and spermatids after 8.5 days of FSH withdrawal demonstrated that FSH also supports germ cell maturation in midstages of spermatogenesis (Meachem et al., 1999), probably by supporting germ cell viability. As mentioned above, $15 \%$ of spermatids fail to spermiate following 1 week of FSH Ab treatment (Saito et al., 2000). Thus, these short-term studies highlight the importance of FSH for quantitatively normal spermatogenesis. The precise mechanisms by which FSH acts on each phase of germ cell development are yet to be elucidated.

\section{OTHER EXPERIMENTAL PARADIGMS}

While we have approached the issue of the regulation of spermatogenesis using hormonal manipulation in adult rats, other approaches using congenital or transplantation techniques have been described in the past 10 years that also provide novel insights and are briefly described below for completeness. As with all such models of congenital deficiency, they provide valuable insight into the roles of the gonadotropins during sexual development and in the initiation of spermatogenesis. Their utility in studying the control of spermatogenesis in the adult, however, is reduced due to the likelihood of defects in reproductive development during the fetal and postnatal period, which could confound observations in adult animals.

Knockout mouse models have been produced for the key components of the hypothalamo-pituitary-testicular axis, including the GnRH gene (hpg), FSH and LH receptors, FSH and LH $\beta$ subunits, estrogen receptors, and the aromatase enzyme. The reproductive phenotypes of such transgenic animals have been the subject of recent reviews and thus will not be considered here (Huhtaniemi and Bartke, 2001; O’Donnell et al., 2001b). Germ cell transplantation models are 
based on the transplantation of spermatogonial stem cells from wild-type or factor-deficient animals into infertile hetero- or homozygous recipients. This innovative approach to the study of spermatogonia has been recently reviewed (McLean et al., 2001; Meachem et al., 2001).

\section{Models Used to Explore Human and Monkey Spermatogenesis}

Exogenous $\mathrm{T}$ markedly suppresses both FSH and $\mathrm{LH}$ in primates and profoundly impairs spermatogenesis, thereby providing a steroidal basis for male hormonal contraception (see below). The addition of progestin also appears to accelerate and perhaps augment the degree of gonadotropin withdrawal (Handelsman et al., 1996; Meriggiola and Bremner, 1997). Using ultra-sensitive assays, serum LH is found to be $<0.3 \%$ of control but FSH remains detectable at 1-2\% (Robertson et al., 2001). This residual FSH secretion appears to be constitutive (i.e., GnRH independent). Exogenous $\mathrm{T}$ does not result in a restoration of serum FSH as in rats; thus, both exogenous LH (in the form of human chorionic gonadotropin (hCG)) and/or FSH can be administered to study their effects on spermatogenesis (Matsumoto and Bremner, 1989). An interesting difference exists between man and monkeys in regard to testicular $\mathrm{T}$ levels in response to such treatment, as $\mathrm{T}$ levels fall to $\approx 2 \%$ of normal in human (McLachlan et al., in press) but to only $\approx 25 \%$ of normal (and many-fold those in serum) in monkeys (Weinbauer et al., 1988; Zhengwei et al., 1998c). This implies a substantial degree of LH-independent androgen secretion in monkeys.

A feature of many T-based contraceptive formulations in man has been the variable induction of azoospermia, ranging from 70 to $95 \%$, depending on the regimen and ethnic group under study (World Health Organization, 1990,1996; Meriggiola et al., 1996; Martin et al., 2000). While sperm counts less than 3 million/ml may provide adequate contraception (World Health Organization, 1996), there is a general consensus that the reliable induction of azoospermia is important to ensure contraceptive efficacy and the widespread acceptance of male hormonal contraception. An understanding of the biological basis for the variable response is essential to this goal.

In order to pursue these issues, we have undertaken a series of studies in man and monkeys aimed at understanding which sites in spermatogenesis are affected by gonadotropin withdrawal and whether various aspects of proposed contraceptive treatments could be modified to augment the degree of suppression. Broadly, these studies have exploited paradigms similar to those being considered for human clinical application. Overall, there are striking similarities between the data from man and monkeys and several directions for further research have emerged. 


\section{A. PRIMATE STUDIES}

The nonhuman primate is an excellent model of human spermatogenesis sharing very similar hormonal dependencies and structural patterns. Studies are very demanding and expensive but allow experimental paradigms not possible in man (e.g., sequential testis biopsies). We have explored their use in studies aimed at understanding the basis of hormonal contraception, namely, $\mathrm{T}$ treatment, either alone or in combination with progestins.

\section{Testosterone Treatment}

We administered $\mathrm{T}$ to adult macaque monkeys using subcutaneous implants for 20 weeks, which provide moderately supraphysiological serum levels in order to suppress gonadotropins. Then, we determined germ cell populations using the optical disector stereological method (O'Donnell et al., 2001a). In all animals, the only acute decrease in germ cell numbers observed was a fall in A pale spermatogonia to $45 \%$ of baseline within 2 weeks. The subsequent depletion of later germ cells was manifest by a decline in type B spermatogonia (32-38\% baseline) and spermatocyte/spermatid numbers (20-30\% baseline) after 14 and 20 weeks. While there was evidence of some minor losses of spermatocytes and spermatids, the reduction in later germ cell types was primarily attributed to a decrease in the conversion of type A pale $\rightarrow$ B spermatogonia. Type B spermatogonia were more markedly suppressed in those animals becoming azoospermic, compared to those who did not. Therefore, the conversion of type A pale $\rightarrow$ type B spermatogonia may be a key point in determining the degree of contraceptive efficacy.

A second observation was the abnormal retention of mature elongated spermatids in some monkeys after long-term $\mathrm{T}$ administration (O'Donnell et al., 2001a). The number of retained spermatids was negatively correlated with sperm count in the ejaculate, suggesting that failure of spermiation contributes to the extent of sperm count suppression during chronic $\mathrm{T}$ treatment in monkeys. Thus, it is clear that both the inhibition of A pale and B spermatogonial development and inhibition of spermiation are the major defects caused by long-term $\mathrm{T}$ administration to monkeys. These observations align closely with those seen in humans (see below) but show some differences compared to rodents (Figure 2).

A number of endocrine parameters were investigated as potential markers that might differentiate animals that did or did not achieve azoospermia. Serum bioactive FSH was found to be the only endocrine marker of this effect that was significantly lower in azoospermic animals (A. Narula, Y.-Q. Gu, L. O'Donnell, P. Stanton, D. Robertson, R. McLachlan, W. Bremner, submitted), which correlated with the lower numbers of $\mathrm{B}$ spermatogonia in these animals (O'Donnell et al., 2001a). These observations support a key role for FSH in spermatogonial development and emphasize the need for FSH suppression in 


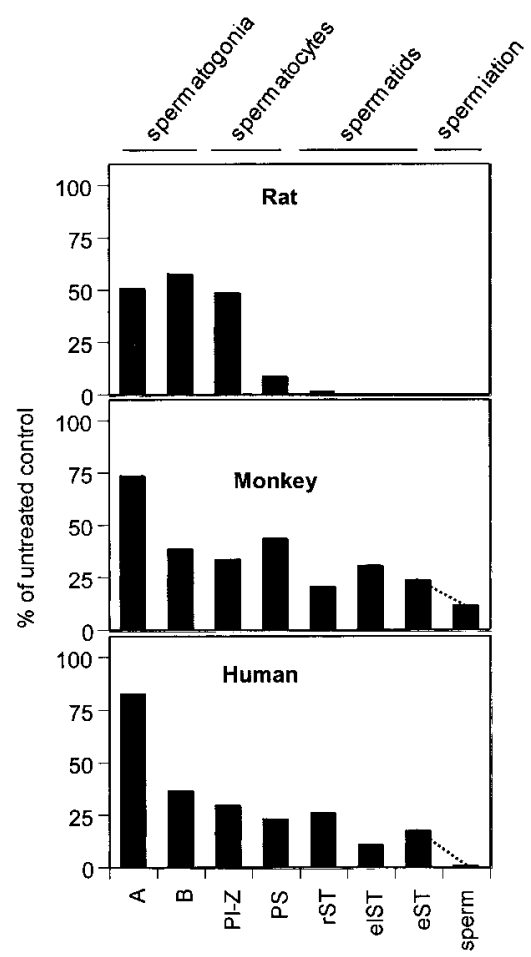

FIG. 2. Comparison of the progression of germ cells through spermatogenesis in rats (upper panel), monkeys (middle panel), and men (lower panel) after 12-14 weeks of combined gonadotropin (LH and FSH) suppression. Germ cell numbers were determined in whole testes in rats and in biopsy material obtained from open testicular biopsies in monkeys and men, using the optical disector stereological approach. Data were expressed on a per-testis or per-Sertoli cell basis. Data in rats are modified from Meachem et al., 1998, in which adult Sprague Dawley rats $(\mathrm{n}=6)$ were immunized against GnRH for 12 weeks, the germ cell populations determined, and expressed as a percentage of a control group of placebo-treated rats $(\mathrm{n}=6)$. Data in monkeys are modified from O'Donnell et al., 2001a, in which adult Macaca fascicularis $(\mathrm{n}=9)$ were administered testosterone implants for 14 weeks. Germ cell populations were determined and expressed as a percentage of germ cells in pretreatment biopsies. Data in humans are modified from our own data on men $(n=5)$ receiving weekly injections of $200 \mathrm{mg} \mathrm{T}$ enanthate for 12 weeks. The germ cell data are expressed as a percentage of an untreated control group $(\mathrm{n}=5$ ) (McLachlan et al., in press). Abbreviations: A, type A spermatogonia; B, type B spermatogonia; PL-Z, preleptotene-zygotene spermatocytes; PS, pachytene spermatocytes; rST, round spermatids; elST, elongating spermatids; eST, elongated spermatids. The dashed line between elongated spermatids (eST) and sperm represents the difference between the number of spermatids in the testis prior to release and the number in the ejaculate, in order to provide insights into the possibility of spermiation failure. These data obtained for monkeys and men after 14 and 12 weeks of gonadotropin suppression respectively, are comparable to the extent of spermatogenic suppression in monkeys and men after 20-24 weeks of gonadotropin suppression (Zhengwei et al., 1998b; O'Donnell et al., 2001a), and thus appear to represent steady-state suppression. 
contraceptive regimens. A similar conclusion that FSH is an important factor in spermatogenic inhibition in T-treated monkeys was recently drawn by Weinbauer and colleagues (2001). Interestingly, in our study, serum inhibin B levels (a potential marker of the Sertoli cell-spermatogenic relationship) declined to about $40 \%$ of baseline but did not differ between azoospermic and non-azoospermic monkeys (A. Narula, Y.-Q. Gu, L. O'Donnell, P. Stanton, D. Robertson, R. McLachlan, W. Bremner, submitted). Testicular androgens also did not differ between groups. However, it was noted that, despite a marked decrease in testicular $\mathrm{T}$ concentrations after exogenous $\mathrm{T}$ administration, the levels of $5 \alpha$-reduced androgenic metabolites were maintained at control levels, suggesting an upregulation of the $5 \alpha$-reductase enzyme in the LH-deprived primate testis (see below).

\section{GnRH Antagonist Treatment}

Our studies of monkeys given a GnRH antagonist for 21 days revealed similar spermatogenic sites for gonadotropin suppression, namely, the conversion of type A pale $\rightarrow$ B spermatogonia and elongated spermatid retention (Zhengwei et al., 1998c). This suggests that GnRH antagonist and moderately supraphysiological $\mathrm{T}$ treatment have similar effects on primate spermatogenesis.

\section{B. HUMAN STUDIES}

\section{Testosterone Treatment}

Testosterone treatment only leads to azoospermia in $\approx 70 \%$ of normal men and to variable degrees of oligospermia in the remainder. However, the basis of this variable response is unclear (World Health Organization, 1990,1996; Handelsman et al., 1995). In order to ascertain the changes in germ cell populations during $\mathrm{T}$ treatment, we undertook a stereological assessment of spermatogenesis in men receiving the same contraceptive regimen as used in the WHO multicentre trial (World Health Organization, 1990). Ten normal, fertile men, already planning to undergo vasectomy, received $\mathrm{T}$ enanthate $(200 \mathrm{mg}$ intramuscularly (im) weekly) for $\approx 20$ weeks prior to testicular biopsy (Zhengwei et al., 1998b). Type B spermatogonia fell markedly to $10 \%$ of the untreated control group and later germ cell types to 11-18\% of controls. Despite the presence of elongated spermatids ( $0.6-20 \%$ of control) in the testis, four men became azoospermic. Two T-treated subjects with similar early germ cell complements and elongated spermatids numbers had sperm counts of $<0.1$ and $21 \mathrm{million} / \mathrm{ml}$. The latter man demonstrated marked variability in germ cell numbers between adjacent tubules. Overall, we concluded that the principal spermatogenic lesion in T-treated men is the marked inhibition of type $\mathrm{A} \rightarrow \mathrm{B}$ spermatogonial maturation, although other sites were also affected, particularly the release of elongated spermatids. It was also striking that a similar degree of gonadotropin withdrawal was associated 
with widely variable spermatogenic patterns, both between and within individuals, the latter being evident in different histological patterns between adjacent tubules, despite exposure to presumably an identical endocrine milieu (Zhengwei et al., 1998b).

\section{Testosterone + Progestin: Effects on Spermatogenesis and Reproductive Endocrinology}

We have also examined the proposition that the co-administration of a progestin with $\mathrm{T}$ enhances the suppression of spermatogenesis. We hypothesised that the greater speed and/or extent of suppression of germ cell number would be correlated with an enhanced suppression of serum gonadotropins and/or testicular androgens levels. Normal, fertile men received either T enanthate $200 \mathrm{mg}$ im weekly alone or in combination with the depot progestin, medroxyprogesterone acetate (DMPA) (McLachlan et al., in press) for 2, 6, or 12 weeks prior to stereological assessment of testis biopsy material. The inclusion of DMPA led to a more rapid fall in serum FSH/LH levels, achieving nadir levels in about half the time. Yet, the mean time to sperm count below 1 million/ $\mathrm{ml}$ (around 25 days) and the maximum extent of FSH/LH suppression (mean serum FSH 1.2-1.6\%, and mean LH $0.2-0.3 \%$ of baseline) did not differ. In both groups, intratesticular $\mathrm{T}$ levels declined similarly to $\approx 2 \%$ of control levels but, as in monkeys, the testicular $5 \alpha$-reduced androgens dihydrotestosterone (DHT) and $5 \alpha$-androstane$3 \alpha 17 \beta$-diol (Adiol) did not fall significantly. The only difference in germ cell numbers was seen at 2 weeks, when type B spermatogonia and early spermatocytes were significantly lower in the T enanthate + DMPA group, presumably reflecting the lower gonadotropin levels at this time. In the longer term, a marked inhibition of A pale $\rightarrow$ B spermatogonial maturation was seen, along with a striking inhibition of spermiation, but no difference was seen in germ cell suppression with or without DMPA.

In summary, it is clear that spermatogonial inhibition is a consistent feature of both acute and chronic gonadotropin withdrawal in these contraceptive models. However, spermiation inhibition is also striking within the first month of treatment and appears to be a major determinant of sperm output. Despite marked reductions in spermatogonia and subsequent germ cells, appreciable germ cell development (10-30\% of normal) continues even after long-term gonadotropin suppression (Figure 2), in comparison to a similar milieu in rats. What factors account for this? Androgen action may support some degree of germ cell development by virtue of the persistence of testicular DHT and Adiol levels. The fact that $\mathrm{T}$ administration with or without added progestin is associated with measurable levels of FSH (Robertson et al., 2001) may suggest some FSHmediated maintenance of spermatogenesis. Yet, to date, a relationship has not 
been seen between the achievement of either azoospermia or oligospermia and residual serum FSH levels in contraceptive trials (Handelsman et al., 1995).

\section{Current Studies Characterising the Mechanisms of Regulation of Hormone-sensitive Sites in Spermatogenesis}

The above studies on the role of FSH and/or $\mathrm{T}$ in the suppression and restoration of adult rat spermatogenesis indicate that both hormones have independent and synergistic effects on germ cell development. Our further studies in primates and humans have demonstrated the relevance of several of these processes - notably, spermatogonial development, sperm release, and testicular androgen biosynthesis - to the contraceptive-treated man. The comparison between rat, monkey, and human spermatogenesis after long-term gonadotropin suppression reveals the similarities between monkeys and humans and the similarities and differences between rats and primates (Figure 2). The identification of hormone-dependent steps has led to further research into the molecular mechanisms by which these processes are regulated. The next section discusses the focus of our more recent work on specific processes in spermatogenesis.

\section{A. REGULATION OF SPERMATOGONIAL DEVELOPMENT}

Spermatogonial stem cells provide a mitotically active lineage committed to both differentiation and renewal of the stem cell population. Both stem cells and differentiating spermatogonia are difficult to study due to their small populations and the lack of morphological and biochemical/molecular markers for identifying their various developmental phases. To date, their basal position and nuclear morphology, together with their stage associations, are the main features used to distinguish each spermatogonial subclass. Three models of spermatogonial renewal have been proposed in rodents (Meistrich and van Beek, 1993), with four subclasses of rat type A spermatogonia (denoted A1-4) as well as intermediate and type B spermatogonia (Clermont, 1972). In the monkey and human, there are two morphologically distinct type A spermatogonial subtypes, A dark (Ad) and A pale (Ap), as well as type B spermatogonia (Clermont, 1972) (Figure 3). Type Ap are proposed to divide to give rise to type $\mathrm{B}$ as well as to renew their own population (Clermont, 1969; van Alphen et al., 1988a,b; Schlatt and Weinbauer, 1994). Type Ad are considered to be the nonproliferative reserve spermatogonial population (Clermont, 1969; van Alphen et al., 1988a,b; Schlatt and Weinbauer, 1994) that may be able to undergo transition to Ap following testicular insult, thereby allowing repopulation of the testis (van Alphen et al., 1988a,b). Ap have been suggested to be the true stem cell of the testis because Ap (not Ad) are seen in humans after radiation (Schulze, 1979), after long-term estrogen therapy, and 


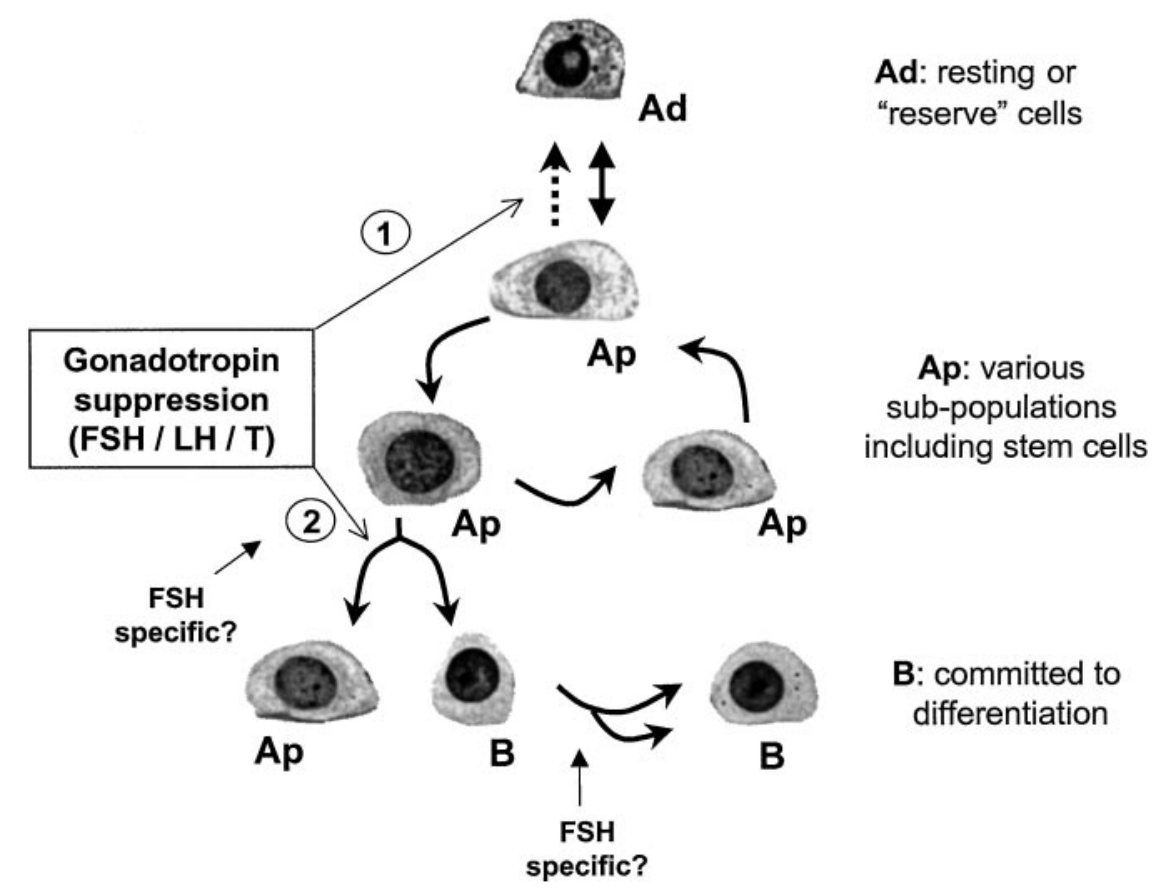

FIG. 3. Hypothesis of the effects of gonadotropin suppression on spermatogonial subtypes in primates. There are three subtypes of spermatogonia, type A pale (Ap) and A dark (Ad) spermatogonia and type B spermatogonia. Ap spermatogonia divide in the later stages of the spermatogenic cycle to produce type B spermatogonia as well as to renew their own population (indicated by the branched arrow). It is likely that different subtypes exist within the Ap category. Since a proportion of Ap spermatogonia are considered to be the true "stem cells" of the testis, there must be subpopulations of stem cell Ap spermatogonia as well as Ap spermatogonia that will give rise to B spermatogonia. Ad spermatogonia rarely divide and are considered to be "resting" or "reserve" stem cells. Type B spermatogonia are produced from the final mitosis of Ap spermatogonia and thus are considered as committed to differentiation. Type B spermatogonia then undergo a series of mitotic divisions (indicated by the branched arrow) before entering meiosis. It should be noted that the exact number of divisions is not indicated. Gonadotropin suppression, in which FSH, LH, and testicular T are suppressed, produces changes in these spermatogonial subtypes. However, in these suppression models, it is not possible to dissect the specific effects of each hormone (see section IV-A). Our data in monkeys and men suggest that gonadotropin suppression causes the "transdifferentiation" of Ap to Ad spermatogonia (dashed arrow), since increases in Ad and decreases in Ap are evident. Gonadotropin suppression also causes an inhibition of the final mitosis of Ap to B spermatogonia, which then leads to decreases in B spermatogonial numbers. This disruption of the final mitosis of Ap spermatogonia may also explain the fact that Ap spermatogonial number decrease with increasing time of gonadotropin suppression. There is evidence for FSH-specific effects (indicated by the arrow) on both the division of Ap into B spermatogonia and within the type B spermatogonial population (see section IV-A). This diagram shows primate (Macaca fascicularis) spermatogonia but is applicable to human spermatogonia. We believe it is likely that some species differences exist in the relative sensitivities of each spermatogonial type to gonadotropin/FSH suppression (see section IV-A). 
in the postpubertal cryptorchid testes (Schulze, 1981). Various studies have suggested that Ap can undergo transition without division into Ad (Fouquet and Dadoune, 1986; van Alphen et al., 1988a,b).

Following FSH/LH withdrawal, type Ap spermatogonia are the first cells to decrease in monkeys, followed by a subsequent decrease in B spermatogonia (O'Donnell et al., 2001a). In man, type B spermatogonia are the first cells to decrease, followed by decreases in type Ap (McLachlan et al., in press). The basis for this species difference is unclear but may relate to different sensitivities of Ap and B spermatogonia to gonadotropin suppression. The fall in the number of type B spermatogonia could be due to an inhibition of Ap spermatogonial mitosis, such as was demonstrated in GnRH antagonist-treated monkeys (Schlatt and Weinbauer, 1994), or by a direct effect on B spermatogonial mitosis (Figure 3).

Studies in cynomolgus monkeys showed that short-term (i.e., 2 weeks) $\mathrm{T}$ administration caused a decrease in type Ap spermatogonia, an increase in Ad spermatogonia, while type B spermatogonia were unchanged (O'Donnell et al., 2001a). This suggests gonadotropin withdrawal results in type Ap spermatogonia ceasing to proliferate into B spermatogonia but instead differentiating into $\mathrm{Ad}$ spermatogonia (Figure 3), as has been suggested by others (Fouquet and Dadoune, 1986). Studies in rhesus monkeys have shown decreases in Ad spermatogonia and increases in B spermatogonia in response to FSH treatment in juvenile monkeys (Ramaswamy et al., 2000b) or in response to the FSH rise induced by unilateral castration (Ramaswamy et al., 2000a). These data support our contention that Ap spermatogonia can produce B spermatogonia upon gonadotropic (presumably FSH) stimulation but can be shunted to "resting" Ad spermatogonia in the absence of such stimulus (Figure 3). Our studies on T-induced gonadotropin suppression in monkeys and man do not allow us to dissect out the relative effects of FSH versus LH/T suppression on spermatogonial subtypes in these species. However, other studies have administered FSH to monkeys to show that FSH alone can increase B spermatogonia (van Alphen et al., 1988c; Marshall et al., 1995; Ramaswamy et al., 2000b), suggesting that some or all of the effects of gonadotropin suppression on spermatogonia is due to the loss of FSH (Figure 3). Certainly, our data in rats would suggest that spermatogonia are regulated primarily by FSH (McLachlan et al., 1995; Meachem et al., 1998,2001).

In fact, there has been little support for the notion that sex steroids or Leydig cell factors stimulate spermatogonial development. In the rat, we found no evidence that $\mathrm{T}$ supports spermatogonial development after long-term gonadotropin depletion (Meachem et al., 1997,1998). Conversely, we have suggested that high serum $\mathrm{T}$ levels produced by exogenous $\mathrm{T}$ administration inhibits the restoration of spermatogonial number (Meachem et al., 1997,1998). Consistent with this, others have provided evidence that high testicular $\mathrm{T}$ levels are 
detrimental to spermatogonial development (Meistrich and Kangasniemi, 1997) and that suppression of testicular $\mathrm{T}$ levels is required to promote spermatogonial development in the irradiated rat and in the juvenile spermatogonial depletion (jsd) mutant mouse (Matsumiya et al., 1999).

\section{B. THE REGULATION OF SPERMIOGENESIS}

Several studies have demonstrated that $\mathrm{T}$ is critical for spermiogenesis (Awoniyi et al., 1989b; Sun et al., 1989; McLachlan et al., 1994a; O'Donnell et al., 1994). As described in Section IIA and Figure 4, suppression of intratesticular T levels impairs the conversion of step $7 \rightarrow 8$ round spermatids due to the premature detachment of step 8 round spermatids from the epithelium. These cells are subsequently found in the epididymis, where they degenerate (O'Donnell et al., 1996a). Based on these data, we (McLachlan et al., 1996; O'Donnell et al., 1996a) and others (Cameron et al., 1993) have hypothesised that androgens regulate adhesion between Sertoli cells and step 8 round spermatids, either via effects on the cell adhesion molecules (CAMs) located between the two cell types, or on the intracellular junctional apparatus located in the Sertoli cell.

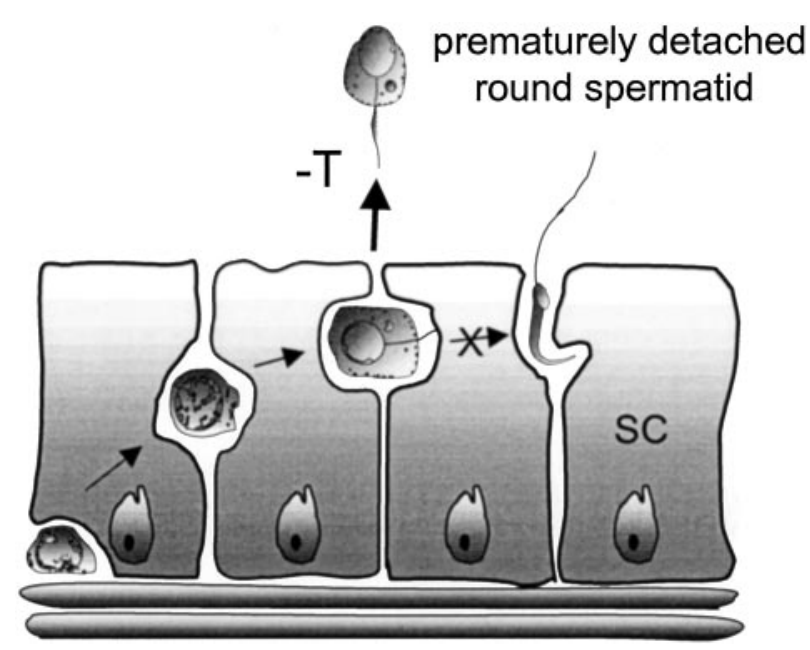

FIG. 4. Diagram of the effects of testicular testosterone (T) suppression by TE treatment on the association between step 8 round spermatids and the seminiferous epithelium. Testicular T suppression causes step 8 round spermatids to lose their attachment from the Sertoli cell (SC) within 3 weeks of testicular $\mathrm{T}$ suppression. The round spermatids proceed to the epididymis, where they degenerate (O’Donnell et al., 1996a). Thus, round spermatids prematurely detach and are unable to complete their elongation into the mature spermatid form, as indicated by the cross. This detachment can be reversed by 4 days of high-dose T replacement (O'Donnell et al., 1994). 
The contribution of FSH to round spermatid adhesion in this rodent model is expected to be permissive rather than regulatory, as FSH levels remain near normal in the above rodent model. However, it is well known that the intracellular organisation of various Sertoli cell cytoskeletal proteins is FSH dependent (Muffly et al., 1994). In vitro evidence has shown that FSH as well as T is required for adhesion between rat Sertoli cells and purified round spermatids (Cameron and Muffly, 1991; Perryman et al., 1996).

Coincident with the appearance of step 8 round spermatids in the normal epithelium is the formation of an adjacent specialised Sertoli cell junctional apparatus called the ectoplasmic specialisation (ES) (see Vogl et al., 2000, for a recent review), which remains during the elongation process and is removed just prior to spermiation. The ES comprises the Sertoli cell plasma membrane, a layer of hexagonally packed, noncontractile actin filaments and an underlying endoplasmic reticulum (Russell et al., 1988; Vogl et al., 2000). The ES is a hormone-sensitive structure, as it is disorganised in hypophysectomised adult rats (Muffly et al., 1993) and can be restored by treatment with FSH (Muffly et al., 1994). We postulated that the detachment of step 8 round spermatids when testicular T levels are low may have been due to the absence of the ES but have recently found that the actin-containing intracellular domain associated with the ES remains qualitatively normal under these circumstances (O'Donnell et al., 2000). This evidence suggests that the androgen-dependent lesion leading to detachment of step 8 round spermatids may lie in the intercellular CAM domain.

Despite extensive morphological data describing the ES, little is known about the identity(ies) or regulation of CAMs at this junction. Linkages between Sertoli cells and the spermatid acrosome have been observed by electron microscopy (Russell et al., 1988), which presumably contribute to a strong adhesive domain as mechanical disruption of the seminiferous epithelium results in spermatids with attached fragments of Sertoli cell cytoplasm containing ES (Romrell and Ross, 1979). One candidate CAM is $\alpha 6 \beta 1$-integrin, which has been immunolocalised to the junction between Sertoli cells and both round and elongating spermatids (Palombi et al., 1992; Salanova et al., 1995; Mulholland et al., 2001) and may be involved in a signaling complex with integrin-linked kinase (Mulholland et al., 2001). Other data support an involvement for CAMs from the cadherin (Byers et al., 1994; Wine and Chapin, 1999) and protocadherin (Johnson et al., 2000) families. We have demonstrated that N-cadherin production by Sertoli cells in vitro is dose dependent for $\mathrm{T}$ in the presence of FSH (Perryman et al., 1996). As an N-cadherin-specific antibody will also block androgen-stimulated adhesion between Sertoli cells and isolated round spermatids in vitro (Perryman et al., 1996), N-cadherin may be one of the CAMs that subserves this process. Proof of the importance of the androgenic regulation of CAM function in round spermatid adhesion in vivo is lacking. However, we have recently demonstrated that the mRNAs for $\beta 1$-integrin, $\mathrm{N}$-cadherin, and $\beta$-cate- 
nin are all significantly upregulated by $\mathrm{T}$ replacement in the rat model (P.G. Stanton, N.F. Cahir, L. O'Donnell, D.M. Robertson, unpublished data), highlighting their potential significance.

In contrast to the T-deficient rat, there is no evidence to support a major midspermiogenic lesion in monkeys or man following suppression of gonadotropins (Zhengwei et al., 1998b,c; O'Donnell et al., 2001a) (Figure 2). Although some round spermatids are seen in ejaculates of men following gonadotropin withdrawal, their number is low and does not correlate with the rapid fall in sperm count (Zhengwei et al., 1998a). However, it is important to note that $\mathrm{T}$ treatment suppresses both LH and FSH in man, a situation that is analogous to the GnRH-immunised rat, where spermiogenesis is fully suppressed prior to the production of step 8 spermatids (see Figures 1 and 2). Against this background, an appreciable degree of step 8 round spermatid detachment would not be apparent.

\section{THE COMBINED ROLE OF FSH AND TESTOSTERONE IN THE REGULATION OF SPERMIATION}

Although normal spermiation is clearly important for determining the sperm output from the testis, relatively little is known of the molecular control of this process. Immunocytochemical localisation studies have revealed the presence of several cell adhesion molecules and their associated proteins encompassing the spermatid head prior to release, such as $\mathrm{N}$-cadherin and catenin (Wine and Chapin, 1999), $\beta 1$-integrin (Palombi et al., 1992; Salanova et al., 1995; Mulholland et al., 2001) and its associated kinase integrin-linked kinase (ILK) (Mulholland et al., 2001). Other cytoskeletal and signaling molecules are present in the Sertoli cell at this stage (Wine and Chapin, 1999), which may be important in the control of adhesion between the spermatid and the Sertoli cell as well as for the subsequent disengagement of the spermatid during spermiation. Several lines of data suggest that sperm release is mediated by the Sertoli cell and that FSH and T activate similar pathways. These include 1) spermiation in rats in vivo appears to be regulated synergistically by FSH and T (Saito et al., 2000); 2) only Sertoli cells contain the receptors for these hormones; and 3) mature elongated spermatids are transcriptionally inactive.

Given that little is known of the molecular processes controlling normal spermiation, the regulation of spermiation failure is equally unclear. Marked spermiation failure occurs within a matter of days after hormone suppression, suggesting that the loss of FSH and T action on Sertoli cells either results in the loss of a "spermiation signal" and/or the initiation of processes required for spermatid retention. The fact that spermatids and Sertoli cells seem to interact via CAMs, and that most of the morphological events leading up to spermatid disengagement appear relatively normal on light microscopy during spermiation failure (A. Beardsley, 
L. O'Donnell, unpublished data), leads us to speculate that it is the actual disengagement (i.e., loss of adhesion) process that is impaired during spermiation failure, as has been speculated by others (Wine and Chapin, 1999).

Thus, it seems that the Sertoli cell fails to release the spermatid and phagocytosis then follows. Our efforts are now focused on characterising the changes in the expression, localisation, and phosphorylation status of putative spermiation-associated molecules, including CAMs, related downstream signaling molecules and kinases, both in normal rats and in those in which spermiation failure has been induced.

Further studies on the hormonal regulation of spermiation in humans are necessary to understand the relative sensitivities of this process to FSH and T suppression and whether various contraceptive regimes have differential effects on spermiation. The hypothesis that more profound suppression of gonadotropins would be more likely to lead to spermiation failure is supported by studies using combined $\mathrm{T}$ plus progestin contraceptive regimes in which the rapid suppression of sperm counts (<6 weeks) was seen (Meriggiola et al., 1996). It remains to be seen whether spermiation failure contributes to the heterogeneity in the suppression of sperm counts: Do men who remain oligospermic do so because spermiation failure does not occur? Further consideration ought be given to contraceptive formulations that target spermiation in humans, as they may provide more rapid and effective suppression of sperm count.

\section{THE ROLE OF $5 \alpha$-REDUCED ANDROGENS IN REGULATING SPERMATOGENESIS}

Our previous studies (O'Donnell et al., 1999) showed that blockade of androgen action in the testis by the administration of the AR antagonist, flutamide, increased the production of testicular $5 \alpha$-reduced metabolites, such that a significant increase in the concentration of testicular DHT and Adiol was observed, compared to vehicle-treated animals. This increase in $5 \alpha$-reduced metabolites occurred in the absence of changes in testicular $\mathrm{T}$ or serum $\mathrm{LH}$, suggesting that T may negatively regulate the $5 \alpha$-reductase $(5 \alpha \mathrm{R})$ enzyme. This was particularly interesting in view of the fact that exogenous $\mathrm{T}$ treatment to monkeys and men causes a marked decrease in testicular $\mathrm{T}$ levels, yet a maintenance of testicular $5 \alpha$-reduced androgens (see section III). These studies prompted further examination of testicular $5 \alpha$-reductase expression and regulation.

Two $5 \alpha \mathrm{R}$ genes - termed type $1(5 \alpha \mathrm{R}-1)$ and type $2(5 \alpha \mathrm{R}-2)$ - have been identified in humans and rats (for a review, see Russell and Wilson, 1994). $5 \alpha \mathrm{R}-1$ has a micromolar affinity for steroid substrates and a broad neutral $\mathrm{pH}$ range of activity, whereas $5 \alpha \mathrm{R}-2$ has a nanomolar affinity for steroid substrates and optimum activity at pH 5.0 (Normington and Russell, 1992). The cellular site and 
type of $5 \alpha \mathrm{R}$ isoform expressed in the rat testis is unclear, with conflicting evidence to show that either $5 \alpha \mathrm{R}-1$ or $5 \alpha \mathrm{R}-2$ is the predominant enzyme expressed in the testis (Normington and Russell, 1992; Viger and Robaire, 1995). Our studies show that both isoenzymes are present in the testis but that $5 \alpha \mathrm{R}-1$ is the predominant form (Pratis et al., 2000).

To examine the role of the $5 \alpha \mathrm{R}$ in the regulation of rat spermatogenesis, we studied the restoration of spermiogenesis following $\mathrm{T}$ treatment in the presence or absence of a $5 \alpha \mathrm{R}$ inhibitor. When submaximal levels of $\mathrm{T}$ were administered ( $\leq 10$-cm implants), the co-treatment with a $5 \alpha \mathrm{R}$ inhibitor impaired the restoration of step 8 round spermatids (O'Donnell et al., 1996b) and, subsequently, the production of mature spermatids (O'Donnell et al., 1999).

In humans, there is evidence to suggest that the inability of T-based contraceptive regimens to consistently reach azoospermia is due to differences in $5 \alpha \mathrm{R}$ activity between subjects. Anderson and colleagues (1996) showed that, in response to $\mathrm{T}$ enanthate, plasma DHT levels increased in men, compared to pretreatment. Interestingly, plasma DHT levels in men achieving oligospermia were significantly greater than those men who achieved azoospermia, despite no differences being seen in plasma T levels, presumably reflecting their higher $5 \alpha \mathrm{R}$ activity. These findings provide evidence to suggest that ongoing low levels of sperm production in oligospermic men may be due to upregulation of $5 \alpha \mathrm{R}$ activity in the reproductive tract.

To summarise, data in rats (O'Donnell et al., 1999; and K. Pratis, L. O'Donnell, G. Ooi, P. Stanton, R. McLachlan, D. Robertson, unpublished data) and humans (Anderson et al., 1996,1997) suggest that $5 \alpha$-reduction of $\mathrm{T}$ to DHT in a setting of reduced testicular T concentrations (i.e., during contraceptive administration), via up-regulation of the $5 \alpha \mathrm{R}$ enzyme, may provide an increased androgen stimulus to promote low levels of sperm production in the presence of reduced concentrations of gonadotropins. The preferred pathway of androgen action may depend on the concentration of intratesticular $\mathrm{T}$ (Figure 5). In the normal testis, we suggest that $\mathrm{T}$ would be the preferred ligand for the androgen receptor; however, during suppression of intratesticular $\mathrm{T}$, the more potent androgen DHT would be the preferred ligand.

Two recent human clinical trials have employed a $5 \alpha \mathrm{R}$ inhibitor during T-based hormonal contraception in order to see whether better contraceptive suppression is achieved. The $5 \alpha \mathrm{R}-2$ specific inhibitor, finasteride, was coadministered with T pellets (McLachlan et al., 2000) or T pellets in combination with desogestrel (Kinniburgh et al., 2001). Both studies showed that the addition of finasteride did not enhance spermatogenic suppression. Although these studies do not support the proposition that the inclusion of $5 \alpha \mathrm{R}$ inhibitors assists in obtaining consistent azoospermia, it must be noted that inhibition of both $5 \alpha \mathrm{R}-1$ and $5 \alpha \mathrm{R}-2$ (by combined single or dual inhibitors) may provide a better alternative to finasteride. 
(a) Normal testis

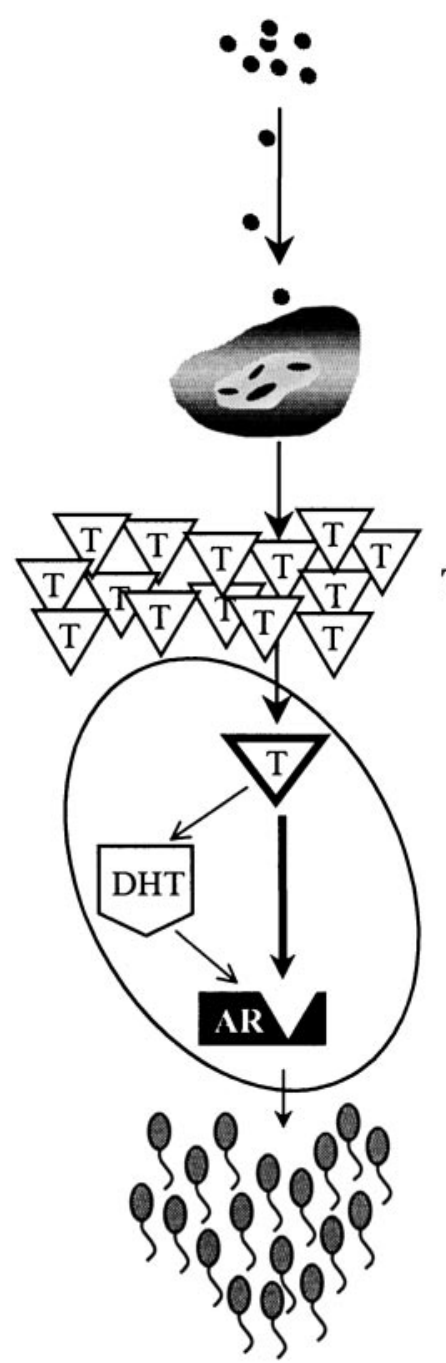

(b) T-suppressed testis

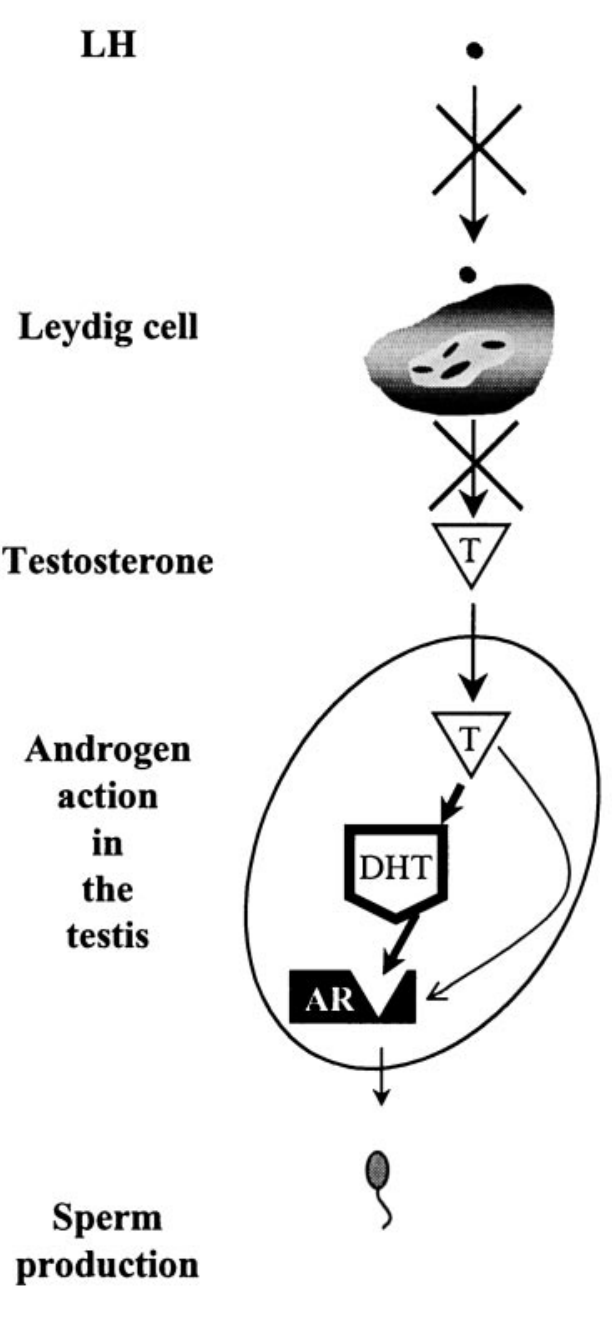

FIG. 5. Androgen action in normal and testosterone-suppressed testes. (A) In the normal testis, LH stimulation of Leydig cell steroidogenesis provides the testis with high local concentrations of testosterone, to act directly on the AR to maintain sperm production. (B) In the testosteronesuppressed testis, the low concentration of testosterone is unable to maintain spermatogenesis. However, conversion of testosterone to the more potent androgenic DHT, via the $5 \alpha$ R enzyme, allows low-level sperm production, despite gonadotropin and testosterone suppression. 


\section{E. RELEVANCE TO RESEARCH INTO MALE FERTILITY REGULATION}

Our present view of potential sites for hormonal manipulation of spermatogenesis centre on two steps in the process: the inhibition of spermatogonial replication and maturation, and spermiation failure. It appears that FSH withdrawal is critical for the former, while both FSH and T are critical for the latter. It is apparent, however, that the inhibitory processes involved in both cases are poorly understood, leading to variability in degree and time to full suppression.

Wider testing of hormonal contraception with regimens including $\mathrm{T}$ plus progestin is underway worldwide and is likely to provide effective contraception in $>95 \%$ of men. After the "proof-of-concept" work undertaken over recent years by public sector agencies, notably WHO and Contraceptive Research and Development Program, funded by the U.S. Agency for International Development, there is now pharmaceutical interest in product development. However, the fundamental goal of achieving uniform induction of azoospermia has not been achieved. Furthermore, differences between men in the speed of induction and recovery of spermatogenesis remain unexplained.

Our future studies will be directed to clarifying the underlying factors responsible for this variability, with the following hormonal and spermatogenic issues being considered worthy of study:

1. The need for the suppression of serum gonadotropins at a maximum rate and as profoundly as possible. Better suppression of gonadotropins is likely to be important for a more rapid onset of suppression of sperm counts (due to the induction of spermiation failure) and a more uniform induction of azoospermia. It is clear that sperm count suppression is poorer when gonadotropins are only partially suppressed (Matsumoto, 1990; Handelsman et al., 1996; McLachlan et al., 2000). However, the hypothesis that failure to fully suppress serum gonadotropins (i.e., to $<5 \%$ of baseline) correlates with the failure to achieve azoospermia has so far not been borne out (Handelsman et al., 1995). Alternative agents that more profoundly suppress gonadotropin levels, such as specific inhibitors and receptor antagonists, may be useful in this respect.

2. As discussed above, there is a need to consider larger trials of $5 \alpha \mathrm{R}$ inhibitors in conjunction with contraceptive formulations. Combined type 1 and $25 \alpha \mathrm{R}$ inhibition would ensure more profound suppression of testicular androgen action, which may be important for the maintenance of spermatogenesis and is likely to be beneficial for the prevention of adverse androgen-dependent effects, particularly on prostate and skin.

3. Finally, a better understanding of the molecular mechanisms of spermiation may allow the design of strategies to specifically block sperm release, thereby providing for a more rapid onset of effectiveness, which would be desirable in clinical practice. Further understanding of spermatogonial prolifer- 
ation and differentiation is needed to allow the development of strategies to more profoundly inhibit the entry of spermatogonia into the spermatogenic process. Such therapies are necessary for the more uniform induction of azoospermia, as indicated in monkeys.

\section{Conclusions}

We have used a range of rat, monkey, and human models to show that FSH and androgens act both separately and synergistically to support a range of key events in spermatogenesis, from spermatogonial stem cell division through to final sperm release. All of these events have been demonstrated using objective and quantitative techniques of germ cell enumeration. We continue to examine the basic mechanisms of these specific hormonal-dependent events using biochemical and molecular approaches. Through identification of these processes, new developments in male hormonal contraception can be expected. The majority of idiopathic male infertility is most likely due to genetic factors, with little or no hormonal basis (de Kretser et al., 2000). But it must be stressed that a better understanding of the physiology of normal spermatogenesis will provide valuable leads in areas such as infertility due to the failure of stem cell proliferation or of germ cells to mature beyond a particular developmental point. Knowledge of the regulation of normal spermatogenesis will facilitate the interpretation of genotype-phenotype relationships in male infertility and permit the definition of new diagnostic categories and perhaps treatments in this difficult field.

\section{ACKNOWLEDGMENTS}

This review was supported by a Program Grant (\#983212) from the National Health and Medical Research Council of Australia (NH\&MRC) and the Wellcome Trust Fellowship Scheme (SM \#058479).

\section{REFERENCES}

Anderson RA, Wallace AM, Wu FC 1996 Comparison between testosterone enanthate-induced azoospermia and oligozoospermia in a male contraceptive study. III. Higher 5 alpha-reductase activity in oligozoospermic men administered supraphysiological doses of testosterone. J Clin Endocrinol Metab 81:902-908

Anderson RA, Kelly RW, Wu FC 1997 Comparison between testosterone enanthate-induced azoospermia and oligozoospermia in a male contraceptive study. V. Localization of higher 5 alpha-reductase activity to the reproductive tract in oligozoospermic men administered supraphysiological doses of testosterone. J Androl 18:366-371

Aslam H, Rosiepen G, Krishnamurthy H, Arslan M, Clemen G, Nieschlag E, Weinbauer GF 1999 The cycle duration of the seminiferous epithelium remains unaltered during GnRH antagonist-induced testicular involution in rats and monkeys. J Endocrinol 161:281-288 
Awoniyi CA, Santulli R, Chandrashekar V, Schanbacher BD, Zirkin BR 1989a Quantitative restoration of advanced spermatogenic cells in adult male rats made azoospermic by active immunization against luteinizing hormone or gonadotropin-releasing hormone. Endocrinology 125:1303-1309.

Awoniyi CA, Santulli R, Sprando RL, Ewing LL, Zirkin BR 1989b Restoration of advanced spermatogenic cells in the experimentally regressed rat testis: quantitative relationship to testosterone concentration within the testis. Endocrinology 124:1217-1223

Awoniyi CA, Sprando RL, Santulli R, Chandrashekar V, Ewing LL, Zirkin BR 1990 Restoration of spermatogenesis by exogenously administered testosterone in rats made azoospermic by hypophysectomy or withdrawal of luteinizing hormone alone. Endocrinology 127:177-184

Byers SW, Sujarit S, Jegou B, Butz S, Hoschutzky H, Herrenknecht K, MacCalman C, Blaschuk OW 1994 Cadherins and cadherin-associated molecules in the developing and maturing rat testis. Endocrinology 134:630-639

Cameron DF, Muffly KE 1991 Hormonal regulation of spermatid binding. J Cell Sci 100:623-633

Cameron DF, Muffly KE, Nazian SJ 1993 Reduced testosterone during puberty results in a midspermiogenic lesion. Proc Soc Exp Biol Med 202:457-464.

Clermont Y 1969 Two classes of spermatogonial stem cells in the monkey (Cercopithecus aethiops). Am J Anat 126:57-71

Clermont Y 1972 Kinetics of spermatogenesis in mammals: seminiferous epithelium cycle and spermatogonial renewal. Physiol Rev 52:198-236

Clermont Y, Harvey SC 1965 Duration of the cycle of the seminiferous epithelium of normal, hypophysectomized and hypophysectomized-hormone treated albino rats. Endocrinology 76:80-89

de Kretser DM, Kerr JB 1988 The cytology of the testis. In: Knobil E, Neill JD, eds. The Physiology of Reproduction, vol. 1. New York: Raven Press Ltd.; 837-932

de Kretser DM, O'Bryan MK, Cram D, McLachlan RI 2000 Expanding our understanding of spermatogenesis: the future genetic tests for infertility. Intl J Androl 23:30-33

de Rooij DG, van Alphen MM, van de Kant HJ 1986 Duration of the cycle of the seminiferous epithelium and its stages in the rhesus monkey (Macaca mulatta). Biol Reprod 35:587-591

El Shennawy A, Gates RJ, Russell LD 1998 Hormonal regulation of spermatogenesis in the hypophysectomized rat: cell viability after hormonal replacement in adults after intermediate periods of hypophysectomy. J Androl 19:320-334; discussion 341-322

Fouquet JP, Dadoune JP 1986 Renewal of spermatogonia in the monkey (Macaca fascicularis). Biol Reprod 35:199-207

Handelsman DJ, Farley TM, Peregoudov A, Waites GM 1995 Factors in nonuniform induction of azoospermia by testosterone enanthate in normal men. World Health Organization Task Force on Methods for the Regulation of Male Fertility. Fertil Steril 63:125-133

Handelsman DJ, Conway AJ, Howe CJ, Turner L, Mackey MA 1996 Establishing the minimum effective dose and additive effects of depot progestin in suppression of human spermatogenesis by a testosterone depot. J Clin Endocrinol Metab 81:4113-4121

Hayes FJ, DeCruz S, Seminara SB, Boepple PA, Crowley WF Jr 2001 Differential regulation of gonadotropin secretion by testosterone in the human male: absence of a negative feedback effect of testosterone on follicle-stimulating hormone secretion. J Clin Endocrinol Metab 86:53-58

Heller CG, Clermont Y 1963 Spermatogenesis in man: an estimation of its duration. Science 140:184-186

Heller CG, Clermont Y 1964 Kinetics of the germinal epithelium in man. Recent Prog Horm Res 20:545-575

Huhtaniemi I, Bartke A 2001 Perspective: male reproduction. Endocrinology 142:2178-2183 
Johnson KJ, Patel SR, Boekelheide K 2000 Multiple cadherin superfamily members with unique expression profiles are produced in rat testis. Endocrinology 141:675-683

Johnston DS, Russell LD, Friel PJ, Griswold MD 2001 Murine germ cells do not require functional androgen receptors to complete spermatogenesis following spermatogonial stem cell transplantation. Endocrinology 142:2405-2408

Kangasniemi M, Wilson G, Parchuri N, Huhtaniemi I, Meistrich ML 1995 Rapid protection of rat spermatogenic stem cells against procarbazine by treatment with a gonadotropin-releasing hormone antagonist (Nal-Glu) and an antiandrogen (flutamide). Endocrinology 136:28812888

Kinniburgh D, Anderson RA, Baird DT 2001 Suppression of spermatogenesis with desogestrel and testosterone pellets is not enhanced by addition of finasteride. J Androl 22:88-95

Leblond CP, Clermont Y 1952 Definition of the stages of the cycle of the seminiferous epithelium in the rat. Ann NY Acad Sci 55:548-573

Marshall GR, Zorub DS, Plant TM 1995 Follicle-stimulating hormone amplifies the population of differentiated spermatogonia in the hypophysectomized testosterone-replaced adult rhesus monkey (Macaca mulatta). Endocrinology 136:3504-3511

Martin CW, Riley SC, Everington D, Groome NP, Riemersma RA, Baird DT, Anderson RA 2000 Dose-finding study of oral desogestrel with testosterone pellets for suppression of the pituitary-testicular axis in normal men. Hum Reprod 15:1515-1524

Matsumiya K, Meistrich ML, Shetty G, Dohmae K, Tohda A, Okuyama A, Nishimune Y 1999 Stimulation of spermatogonial differentiation in juvenile spermatogonial depletion (jsd) mutant mice by gonadotropin-releasing hormone antagonist treatment. Endocrinology 140: 4912-4915

Matsumoto AM 1990 Effects of chronic testosterone administration in normal men: safety and efficacy of high dosage testosterone and parallel dose-dependent suppression of luteinizing hormone, follicle-stimulating hormone, and sperm production. J Clin Endocrinol Metab 70:282-287.

Matsumoto AM, Bremner WJ 1989 Endocrine control of human spermatogenesis. J Steroid Biochem 33:789-790

McLachlan RI, Wreford NG, Meachem SJ, De Kretser DM, Robertson DM 1994a Effects of testosterone on spermatogenic cell populations in the adult rat. Biol Reprod 51:945-955

McLachlan RI, Wreford NG, Tsonis C, De Kretser DM, Robertson DM 1994b Testosterone effects on spermatogenesis in the gonadotropin-releasing hormone-immunized rat. Biol Reprod 50:271-280

McLachlan RI, Wreford NG, de Kretser DM, Robertson DM 1995 The effects of recombinant follicle-stimulating hormone on the restoration of spermatogenesis in the gonadotropinreleasing hormone-immunized adult rat. Endocrinology 136:4035-4043

McLachlan RI, Wreford NG, O'Donnell L, de Kretser DM, Robertson DM 1996 The endocrine regulation of spermatogenesis: independent roles for testosterone and FSH. J Endocrinol 148:1-9

McLachlan RI, McDonald J, Rushford D, Robertson DM, Garrett C, Baker HW 2000 Efficacy and acceptability of testosterone implants, alone or in combination with a 5alpha-reductase inhibitor, for male hormonal contraception. Contraception 62:73-78

McLachlan RI, O'Donnell L, Stanton PG, Balourdos G, Frydenberg M, de Kretser DM, Robertson DM 2002 Effects of testosterone plus medroxyprogesterone acetate on semen quality, reproductive hormones, and germ cell populations in normal young men. J Clin Endocrinol Metab, in press

McLean DJ, Johnston DS, Russell LD, Griswold MD 2001 Germ cell transplantation and the study of testicular function. Trends Endocrinol Metab 12:16-21. 
Meachem S, von Schonfeldt V, Schlatt S 2001 Spermatogonia: stem cells with a great perspective. Reproduction 121:825-834.

Meachem SJ, Wreford NG, Robertson DM, McLachlan RI 1997 Androgen action on the restoration of spermatogenesis in adult rats: effects of human chorionic gonadotrophin, testosterone and flutamide administration on germ cell number. Intl J Androl 20:70-79

Meachem SJ, Wreford NG, Stanton PG, Robertson DM, McLachlan RI 1998 Follicle-stimulating hormone is required for the initial phase of spermatogenic restoration in adult rats following gonadotropin suppression. J Androl 19:725-735

Meachem SJ, McLachlan RI, Stanton PG, Robertson DM, Wreford NG 1999 FSH immunoneutralization acutely impairs spermatogonial development in normal adult rats. J Androl 20:756-762; discussion 755

Meistrich ML, Kangasniemi M 1997 Hormone treatment after irradiation stimulates recovery of rat spermatogenesis from surviving spermatogonia. J Androl 18:80-87

Meistrich ML, van Beek ME 1993 Spermatogonial stem cells. In: Desjardins C, Ewing LL, eds. Cell and Molecular Biology of the Testis. New York: Oxford University Press; 266-295

Meriggiola MC, Bremner WJ, Paulsen CA, Valdiserri A, Incorvaia L, Motta R, Pavani A, Capelli M, Flamigni C 1996 A combined regimen of cyproterone acetate and testosterone enanthate as a potentially highly effective male contraceptive. J Clin Endocrinol Metab 81:3018-3023

Meriggiola MC, Bremner WJ 1997 Progestin-androgen combination regimens for male contraception. J Androl 18:240-244

Muffly KE, Nazian SJ, Cameron DF 1993 Junction-related Sertoli cell cytoskeleton in testosteronetreated hypophysectomized rats. Biol Reprod 49:1122-1132

Muffly KE, Nazian SJ, Cameron DF 1994 Effects of follicle-stimulating hormone on the junction-related Sertoli cell cytoskeleton and daily sperm production in testosterone-treated hypophysectomized rats. Biol Reprod 51:158-166

Mulholland DJ, Dedhar S, Vogl AW 2001 Rat seminiferous epithelium contains a unique junction (ectoplasmic specialization) with signaling properties both of cell/cell and cell/matrix junctions. Biol Reprod 64:396-407

Normington K, Russell DW 1992 Tissue distribution and kinetic characteristics of rat steroid 5 alpha-reductase isozymes. Evidence for distinct physiological functions. J Biol Chem 267: $19548-19554$

O'Donnell L, McLachlan RI, Wreford NG, Robertson DM 1994 Testosterone promotes the conversion of round spermatids between stages VII and VIII of the rat spermatogenic cycle. Endocrinology 135:2608-2614

O'Donnell L, McLachlan RI, Wreford NG, de Kretser DM, Robertson DM 1996a Testosterone withdrawal promotes stage-specific detachment of round spermatids from the rat seminiferous epithelium. Biol Reprod 55:895-901

O'Donnell L, Stanton PG, Wreford NG, Robertson DM, McLachlan RI 1996b Inhibition of 5 alpha-reductase activity impairs the testosterone-dependent restoration of spermiogenesis in adult rats. Endocrinology 137:2703-2710

O’Donnell L, Pratis K, Stanton PG, Robertson DM, McLachlan RI 1999 Testosterone-dependent restoration of spermatogenesis in adult rats is impaired by a 5alpha-reductase inhibitor. $\mathrm{J}$ Androl 20:109-117

O'Donnell L, Stanton PG, Bartles JR, Robertson DM 2000 Sertoli cell ectoplasmic specializations in the seminiferous epithelium of the testosterone-suppressed adult rat. Biol Reprod 63:99108

O'Donnell L, Narula A, Balourdos G, Gu YQ, Wreford NG, Robertson DM, Bremner WJ, McLachlan RI 2001a Impairment of spermatogonial development and spermiation after 
testosterone-induced gonadotropin suppression in adult monkeys (Macaca fascicularis). J Clin Endocrinol Metab 86:1814-1822

O'Donnell L, Robertson KM, Jones ME, Simpson ER 2001b Estrogen and spermatogenesis. Endocr Rev 22:289-318

Orth JM 1993 Cell biology of testicular development in the fetus and neonate. In: Desjardins C, Ewing LL, eds. Cell and Molecular Biology of the Testis. New York: Oxford University Press; 3-43

Palombi F, Salanova M, Tarone G, Farini D, Stefanini M 1992 Distribution of beta 1 integrin subunit in rat seminiferous epithelium. Biol Reprod 47:1173-1182

Perryman KJ, Stanton PG, Loveland KL, McLachlan RI, Robertson DM 1996 Hormonal dependency of neural cadherin in the binding of round spermatids to Sertoli cells in vitro. Endocrinology 137:3877-3883

Pratis K, O'Donnell L, Ooi GT, McLachlan RI, Robertson DM 2000 Enzyme assay for 5alpha-reductase type 2 activity in the presence of 5alpha-reductase type 1 activity in rat testis. J Steroid Biochem Mol Biol 75:75-82

Ramaswamy S, Marshall GR, McNeilly AS, Plant TM 2000a Dynamics of the follicle-stimulating hormone (FSH)-inhibin B feedback loop and its role in regulating spermatogenesis in the adult male rhesus monkey (Macaca mulatta) as revealed by unilateral orchidectomy. Endocrinology 141:18-27

Ramaswamy S, Plant TM, Marshall GR 2000b Pulsatile stimulation with recombinant single chain human luteinizing hormone elicits precocious Sertoli cell proliferation in the juvenile male rhesus monkey (Macaca mulatta). Biol Reprod 63:82-88

Robertson DM, Pruysers E, Stephenson T, Pettersson K, Morton S, McLachlan RI 2001 Sensitive LH and FSH assays for monitoring low serum levels in men undergoing steroidal contraception. Clin Endocrinol 55:331-339

Romrell LJ, Ross MH 1979 Characterization of Sertoli cell-germ cell junctional specializations in dissociated testicular cells. Anat Rec 193:23-41.

Russell DW, Wilson JD 1994 Steroid 5 alpha-reductase: two genes/two enzymes. Annu Rev Biochem 63:25-61

Russell LD 1991 The perils of sperm release - "let my children go." Intl J Androl 14:307-311

Russell LD, Clermont Y 1977 Degeneration of germ cells in normal, hypophysectomized and hormone treated hypophysectomized rats. Anat Rec 187:347-366

Russell LD, Alger LE, Nequin LG 1987 Hormonal control of pubertal spermatogenesis. Endocrinology 120:1615-1632

Russell LD, Goh JC, Rashed RM, Vogl AW 1988 The consequences of actin disruption at Sertoli ectoplasmic specialization sites facing spermatids after in vivo exposure of rat testis to cytochalasin D. Biol Reprod 39:105-118

Russell LD, Ettlin RA, Sinha Hikim AP, Clegg ED 1990 Histological and Histopathological Evaluation of the Testis. Clearwater, FL: Cache River Press

Saito K, O'Donnell L, McLachlan RI, Robertson DM 2000 Spermiation failure is a major contributor to early spermatogenic suppression caused by hormone withdrawal in adult rats. Endocrinology 141:2779-2785

Salanova M, Stefanini M, De Curtis I, Palombi F 1995 Integrin receptor alpha 6 beta 1 is localized at specific sites of cell-to-cell contact in rat seminiferous epithelium. Biol Reprod 52:79-87

Schlatt S, Weinbauer GF 1994 Immunohistochemical localization of proliferating cell nuclear antigen as a tool to study cell proliferation in rodent and primate testes. Intl $\mathrm{J}$ Androl $17: 214-222$

Schulze C 1979 Morphological characteristics of the spermatogonial stem cells in man. Cell Tiss Res 198:191-199 
Schulze C 1981 Survival of human spermatogonial stem cells in various clinical conditions. Fortschritte Der Andrologie 7:58-68

Schulze W, Rehder U 1984 Organization and morphogenesis of the human seminiferous epithelium. Cell Tiss Res 237:395-407

Sinha Hikim AP, Swerdloff RS 1993 Temporal and stage-specific changes in spermatogenesis of rat after gonadotropin deprivation by a potent gonadotropin-releasing hormone antagonist treatment. Endocrinology 133:2161-2170.

Sinha Hikim AP, Wang C, Leung A, Swerdloff RS 1995 Involvement of apoptosis in the induction of germ cell degeneration in adult rats after gonadotropin-releasing hormone antagonist treatment. Endocrinology 136:2770-2775

Sinha Hikim AP, Swerdloff RS 1999 Hormonal and genetic control of germ cell apoptosis in the testis. Rev Reprod 4:38-47

Sun YT, Irby DC, Robertson DM, de Kretser DM 1989 The effects of exogenously administered testosterone on spermatogenesis in intact and hypophysectomized rats. Endocrinology 125: $1000-1010$

Tapanainen JS, Tilly JL, Vihko KK, Hsueh AJ 1993 Hormonal control of apoptotic cell death in the testis: gonadotropins and androgens as testicular cell survival factors. Mol Endocrinol 7:643-650

van Alphen MM, van de Kant HJ, de Rooij DG 1988a Depletion of the spermatogonia from the seminiferous epithelium of the rhesus monkey after X irradiation. Radiat Res 113:473-486

van Alphen MM, van de Kant HJ, de Rooij DG 1988b Repopulation of the seminiferous epithelium of the rhesus monkey after X irradiation. Radiat Res 113:487-500

van Alphen MM, van de Kant HJ, de Rooij DG 1988c Follicle-stimulating hormone stimulates spermatogenesis in the adult monkey. Endocrinology 123:1449-1455

Viger RS, Robaire B 1995 Steady state steroid 5 alpha-reductase messenger ribonucleic acid levels and immunocytochemical localization of the type 1 protein in the rat testis during postnatal development. Endocrinology 136:5409-5415

Vogl AW, Pfeiffer DC, Mulholland D, Kimel G, Guttman J 2000 Unique and multifunctional adhesion junctions in the testis: ectoplasmic specializations. Arch Histol Cytol 63:1-15

Walsh PC, Swerdloff RS 1973 Biphasic effect of testosterone on spermatogenesis in the rat. Invest Urol 11:190-193

Weinbauer GF, Gockeler E, Nieschlag E 1988 Testosterone prevents complete suppression of spermatogenesis in the gonadotropin-releasing hormone antagonist-treated nonhuman primate (Macaca fascicularis). J Clin Endocrinol Metab 67:284-290

Weinbauer GF, Schlatt S, Walter V, Nieschlag E 2001 Testosterone-induced inhibition of spermatogenesis is more closely related to suppression of FSH than to testicular androgen levels in the cynomolgus monkey model (Macaca fascicularis). J Endocrinol 168:25-38

Wierman ME, Wang C 1990 Androgen selectively stimulates follicle-stimulating hormone-beta mRNA levels after gonadotropin-releasing hormone antagonist administration. Biol Reprod 42:563-571

Wine RN, Chapin RE 1999 Adhesion and signaling proteins spatiotemporally associated with spermiation in the rat. J Androl 20:198-213

World Health Organization Task Force on Methods for the Regulation of Male Fertility 1990 Contraceptive efficacy of testosterone-induced azoospermia in normal men. Lancet 336:955959

World Health Organization Task Force on Methods for the Regulation of Male Fertility 1996 Contraceptive efficacy of testosterone-induced azoospermia and oligozoospermia in normal men. Fertil Steril 65:821-829

Wreford NG 1995 Theory and practice of stereological techniques applied to the estimation of cell number and nuclear volume in the testis. Microsc Res Tech 32:423-436 
Zhengwei Y, Wreford NG, Bremner WJ, Matsumoto AM, Anawalt BA, McLachlan RI 1998a Immature spermatids are not prevalent in semen from men who are receiving androgen-based contraceptive regimens. Fertil Steril 69:89-95

Zhengwei Y, Wreford NG, Royce P, de Kretser DM, McLachlan RI 1998b Stereological evaluation of human spermatogenesis after suppression by testosterone treatment: heterogeneous pattern of spermatogenic impairment. J Clin Endocrinol Metab 83:1284-1291

Zhengwei Y, Wreford NG, Schlatt S, Weinbauer GF, Nieschlag E, McLachlan RI 1998c Acute and specific impairment of spermatogonial development by GnRH antagonist-induced gonadotrophin withdrawal in the adult macaque (Macaca fascicularis). J Reprod Fertil 112:139147

Zirkin BR, Santulli R, Awoniyi CA, Ewing LL 1989 Maintenance of advanced spermatogenic cells in the adult rat testis: quantitative relationship to testosterone concentration within the testis. Endocrinology 124:3043-3049 